\title{
Research Article: Assessment of climate change impacts using SWAT
}

\author{
A. VALLIAMMAI, K. BALATHANDAYUTHAM AND B.J. PANDIAN
}

Article Chronicle: Received :

19.07.2017;

Accepted :

03.08.2017

KeY Words:

Watershed, Climate

change, Hydrology

SWAT
Author for correspondence :

A. VALLIAMMAI

Water Technology,

Centre, Tamil Nadu

Agricultural University, COIMBATORE (T.N.) INDIA

Email : vallimei@

gmail.com

See end of the article for

authors' affiliations
SUMMARY : Change in climate would alter the components of hydrological cycle including water availability, water demand, and water allocation at the global, regional, basin, and at local level. A study was undertaken using Soil and Water Assessment Tool (SWAT) to assess the impact of climate change on hydrology, focusing on trends of precipitation, evapotranspiration and water yield in Palar sub basin of Parambikulam Aliyar Project (PAP) Basin. From the model, for the current climate (1981-2000) it was observed that annual average rainfall of Palar sub basin is $830.13 \mathrm{~mm}$, out of which $463.00 \mathrm{~mm}$ was used by the crops (i.e. evapotranspiration). Overall, the rate of precipitation is higher than evapotranspiration during monsoon and post monsoon periods (May to December). Future climate scenario over the Palar sub basin derived from $16 \mathrm{GCM}$ ensemble at $60 \%$ probability indicate that the annual rainfall, water yield, evapotranspiration would increase with the advancement of time, whereas soil water storage is expected to decrease. In the mid and end century, precipitation is expected to increase by 8.7 and 14.6 per cent and evapotranspiration by 4.6 and 5.2 per cent, respectively from the baseline. The annual soil water storage is predicted to decrease in mid and end century. In the mid century, the annual soil water storage would decrease by 2 per cent from the baseline. In end-century, it is expected to decrease by 4.1 per cent from the baseline. The evapotranspiration is expected to increase in all the seasons with varying magnitude towards mid and end century compared to current conditions indicating more water requirement for cultivation of crops. Hence, research towards economizing water to increase crop productivity is need of the hour.

How to cite this article : Valliammai, A., Balathandayutham, K. and Pandian, B.J. (2017). Assessment of climate change impacts using SWAT. Agric. Update, 12(TECHSEAR-7) : 1788-1793; DOI: 10.15740/HAS/AU/ 12.TECHSEAR(7)2017/1788-1793. 